\title{
Kleistův „Michael Kohlhaas“ jako výraz vášnivé touhy po dosažení spravedlnosti, jakož i další autorova díla vztahující se k problematice ,práva a literatury“6
}

\author{
Radim Seltenreich
}

Univerzita Karlova, Právnická fakulta

Kontaktni e-mail: seltenre@prf.cuni.cz

Kleist's "Michael Kohlhaas" as Expression of Passionate Desire to Achieve Justice, and Other Kleist's Works Related to Problems of "Law and Literature"

\begin{abstract}
:
The article deals with the work of Heinrich von Kleist (1777-1811) in terms of its relation to the problems of "law and literature". It focuses on the fact that this German writer belongs to those great creators who attached extraordinary care to the question of law and justice in his work. At first, the paper deals shortly with the life of this important figure of the German letters. Then the main attention is paid to the nouvelle "Michael Kohlhaas" which might be considered as the most important of his works related to the "law and literature" topic. This is given especially by the general preset of the story in which the main hero fights for the achievement of the justice tirelessly even at the cost of sacrificing his family's happiness and his life. Next part of the paper makes us familiar with certain aspects of the plot. Finally, the other works of Kleist related to the problems of "law and literature" and legal questions involved are analyzed.
\end{abstract}

Key words: law and literature; Heinrich von Kleist; Michael Kohlhaas; justice; legal system

Klíčová slova: právo a literatura; Heinrich von Kleist; Michael Kohlhaas; spravedlnost; právní systém

DOI: $10.14712 / 2464689 X .2021 .32$ 
Snad málokterá próza světové literatury představuje ve svém výsledku výraznější položku v rámci oboru „právo a literatura“, než je právě novela „Michael Kohlhaas“ od Heinricha von Kleista. ${ }^{1}$ Je to pak dáno zejména tím, že děj Kleistem předkládaného prríběhu je nejen výrazem vášnivé touhy jednotlivce po dosažení spravedlnosti, která je mu odpírána, ale vlastně i podrobným popisem právních sporů, které i při nikoliv zcela obvyklých zvratech umožňují učinit si jasnější představu o tehdejším fungování právního systému.

Je ale třeba dodat, že „Michael Kohlhaas“ je jen jedním (jakkoliv zřejmě nejvýznamnějším) kamínkem v mozaice Kleistových literárních pokusů o postižení nejrůznějších aspektů práva a spravedlnosti v životě člověka a společnosti. Jedná se prritom často spíše o jevy neobvyklé až kuriózní, ale právě v nich se dosti pochopitelně nezřídka manifestuje některá podstatná stránka právního systému, která často přes svůj zásadní význam uniká bližší pozornosti.

Možná to vůbec nejdůležitější, co nám při „navyklém chodu práva“ mizí doslova před očima, je napětí mezi právem a spravedlností, kdy může dojít dokonce až k tomu, že formalismus práva ideu spravedlnosti, jíž má přece logicky sloužit, potírá. Tak je tomu do značné míry v Kleistových hrách „Princ Bedřich Homburský“ či „Rozbitý džbán“, problémům poznání pravdy ve sporech s právní zápletkou jsou pak zase věnovány jeho povídky „Souboj“ či „Markýza z O ...“.

Je zřejmé, že chceme-li pochopit význam právní problematiky v tvorbě Heinricha von Kleista, musíme se nejprve obeznámit s podstatnými fakty týkajícími se jeho životní dráhy, protože právě v nich se poměrně logicky skrývá klíč k pochopení jeho poměru k tehdejším (ale i některým nadčasovým) konstantám právního řádu.

\section{Život a dílo Heinricha von Kleista}

Heinrich von Kleist se narodil roku 1777 ve Frankfurtu nad Odrou, přičemž pro jeho další život byl v mnohém určující původ, který jej řadil mezi příslušníky předního pruského šlechtického rodu, ze kterého v minulosti pocházeli i někteří generálové, vysocí diplomaté a úředníci. Ve svém dospívání, mezi jehož významné stíny patřila nepochybně ztráta otce roku 1788, se Kleist obeznámil s díly osvícenských myslitelů, která pak tvořila zajímavé pozadí a protiklad jeho vlastní spíše romantické tvorbě, což však nebylo na překážku volbě životní dráhy, kdy se v duchu převažující rodové tradice nejprve rozhodl pro vojenské povolání. $^{2}$

V jeho rámci se tak ještě ve velmi mladém věku účastnil tažení proti revoluční Francii, jakož i obléhání taktéž revoluční myšlenky sdílející Mohuče, přičemž ovšem postupem doby narůstá jeho rozčarování z vojenského života, s jehož bezduchým drilem a disciplínou se dostává jeho svobodný a po poznání toužící duch nevyhnutelně do rozporu. Proti vůli své rodiny tak dosahuje roku 1799 propuštění z vojenské služby, aby se následně věnoval na univerzitě ve Frankfurtu nad Odrou především studiu matematiky a přírodních

1 Blíže k vymezení tohoto oboru viz kupříkladu kniha POSNER, R. A. Law and Literature. A misunderstood Relation. Cambridge: Harvard University Press, 1994. Není přitom bez zajímavosti, že v rámci směru „právo a literatura“ najdeme mnohem více německy píšících autorů, kteří se ve svém díle fenoménu práva a spravedlnosti cíleně dotkli. Za všechny jmenujme třeba přímo vystudovaného právníka J. W. Goetha či pak z autorů 20. století švýcarského dramatika F. Dürrenmatta.

2 STROMŠÍK, J. Od Grimmelshausena k Dürrenmattovi (Kapitoly z německé literatury). Praha: Nakladatelství H a H, 1994, s. 31-37. 
věd. Téhož roku se seznamuje is Wilhelmine von Zenge, se kterou se o rok později také zasnoubil (později ovšem bylo toto jeho zasnoubení zrušeno).

Vysoké společenské postavení jeho snoubenky (jednalo se o dceru pruského generála) jej ale nutí přerušit započatá studia a přijmout úřednické postavení, prričemž tento jeho nový služební poměr je brzy nato přerušen cestou do Paříže a Švýcarska, kterou se snaží zejména překonat narůstající duševní krizi. Zároveň zde ovšem můžeme sledovat i prvotní snahu o cílevědomější literární tvorbu, jakkoliv i ta je doprovázena tvưrčí krizí, kdy Kleist spálí již hotové části svého dramatu Robert Guiskard. Roku 1803 se nicméně vrací zpět do Pruska a obnovuje své působení v různých státních úřadech (takto pobývá po jistou dobu i v Královci na východě země), přičemž ve vzrušené době napoleonských válek je určitou dobu francouzskými úrady vězněn pro podezření ze špionáže.

V této době se také rozhoduje opustit státní služby a živit se pouze literární prací, př́ičemž po svém propuštění z francouzského zajetí krátce pobývá i v Praze, kde pojímá záměr vydávat týdeník „Germania“, který by měl být orgánem „německé svobody“. Zůstává sice jen u záměru, nicméně po svém návratu do Berlína iniciuje Kleist vydávání „Berlínského večerníku“, které ale musí být po cenzurním zásahu zastaveno. Zhoršující se materiální podmínky společně s prohlubující se depresí tak nakonec Kleista vedou k rozhodnutí spáchat sebevraždu, v níž mu ,doprovod poskytne“ jeho přítelkyně Henriette Vogel postižená nevyléčitelnou rakovinou. Stane se tak dne 21. listopadu 1811 poblíž Berlína. ${ }^{3}$

Pokud se Kleistova literárního díla dotýká, již jsme zmínili, že počátky jeho cílevědomé tvorby spadají zejména do údobí 1801-1804, tedy let, kdy delší dobu pobýval v Paříži a zejména v Thunu ve Švýcarsku. Tehdy právě začíná psát svou veselohru „Rozbitý džbán“, přičemž - jak už řečeno - se potýká také s určitou tvůrčí krizí, v jejímž důsledku spálí i část svého jiného díla. V následujícím období pak pracuje už i na některých svých významných povídkách či přímo novelách, mezi něž spadá zejména právě „Michael Kohlhaas“ a také „Markýza z O ..."Velmi plodná jsou také závěrečná léta jeho života, kdy mimo jiné sepisuje i své drama „Princ Bedřich Homburský'“4

Kleistovo literární dílo je pochopitelně mnohem rozsáhlejší, nicméně zde nám šlo výhradně o to, předestřít základní fakta o jeho životě a zasadit do nich právě ty jeho práce, kterými se zde budeme zabývat, a které se tedy vztahují k problematice fenoménu ,právo a literatura“.

\section{Michael Kohlhaas}

Kleistova novela „Michael Kohlhaas“ je dnes jednoznačně považována za jeden z nejdůležitějších textů tohoto rozsahu, který v německém jazyce vůbec kdy vznikl. Hlavním důvodem pro toto hodnocení je prritom nesporně literární kvalita této práce, v níž Kleist ve velmi sevřeném a působivém vyprávění líčí příběh člověka, který se rozhodl nerezignovat „na svá práva“, byt’ je pro jejich naplnění nakonec nucen obětovat štěstí své i celé své rodiny. A nezůstává jen u toho, nebot' na cestě k dosažení spravedlnosti umírá i jeho žena a on sám je pro způsob, který si pro její naplnění zvolil, nakonec odsouzen k trestu smrti.

Působivost novely je přitom nepochybně dána i nadčasovostí tématu. Vždyt' jistě i dnes vůbec nejsou výjimkami př́ípady, kdy je někdo zkrácen ve svých právech a utrpí na svém

KLEIST, H. Záhadný nesmrtelný. Praha: Mladá fronta, 1980, s. 439-445.

STROMŠÍK, op. cit., s. 37-43. 
majetku, zdraví či i důstojnosti nemalou křivdu, přesto se však rozhodne na něm spáchané bezpráví raději přijmout, než aby podstupoval nejistou, drahou a zdlouhavou cestu soudní nápravy. A o co horší je pak situace, kdy se někdo tímto způsobem spravedlnosti přeci jen domáhá, výsledkem je však z jeho pohledu jen podstatné rozmnožení křivdy výrokem státní moci, jež se zpronevěří své povinnosti, a dá za pravdu mocné protistraně. K již tak nelehké situaci se nyní logicky připojuje i nutnost snést výsměch soudu a akceptovat právo popírající spravedlnost.

Skoro všichni dotčení tak nakonec ale učiní, protože jediná nabízející se alternativa je svémoc, tedy braní práva do vlastních rukou, při níž sice člověk může nabýt kýženého zadostiučinění, cenou, kterou však za to zaplatí, je fakt, že sám propadne právu s následky pro svůj osobní život téměř jistě mnohem horšími, než byly ty, které se tímto způsobem snažil napravit.

A přeci jsou takoví, pro které je pocit utrpěné křivdy násobený nespravedlivým výrokem státní moci natolik nesnesitelný, že se touto cestou vydají. Jinými slovy jsou natolik zasaženi ve své osobní důstojnosti, že nic jiného než napravení nespravedlnosti pro ně již nemá v jejich životě smysl, a jsou pro tento cíl připraveni obětovat doslova cokoliv. Jistě je lze nahlížet jako až monomaniakálně postižené bytosti, kteří sami touto svémocí nezřídka působí další křivdy, na druhé straně je ale lze i obdivovat jako lidi, kteří nás tímto svým ceněním si spravedlnosti a odporem ke zneuctěnému právu učí znát jejich skutečnou a pro lidský život zásadní cenu.

Je tak nesmírně důležité, aby se skrz právo vždy dosahovalo spravedlnosti a v ideálním príípadě nikdy nenastával opak. „At' se naplní spravedlnost, at' zhyne svět““ (fiat iustitia, pereat mundus) je jako heslo nemnoha lidí jistou nadčasovou výzvou k zamyšlení, a málokdy je přemítání nad tímto problémem tak silné, jako když je poskytne silný příběh podaný ve skvostném literárním hávu. ${ }^{5}$

A to je právě i př́běh Kleistova „Michaela Kohlhaase“ (novely vydané v roce 1810 , odmítnuté tehdy J. W. Goethem a naopak později velmi obdivované F. Kafkou), v němž se autor inspiroval skutečnou událostí, která se odehrála v první polovině 16. století. Podle dochovaných pramenů, z nichž ale nejstarší pocházejí až z konce 16. století (ty další pak až ze století 17. a dokonce 18.) žil totiž tehdy v Braniborsku jistý Hans Kohlhase, který se věnoval především obchodu s dobytkem. Při jedné z jeho cest do sousedního Saska byl pak bez důkazů obviněn lidmi jednoho ze zdejších šlechticů, že ukradl koně, které měl tehdy při sobě. Musel je tedy zanechat na místě, aby však, když se následně vrátil s důkazy o jejich poctivém nabytí, zjistil, že tito koně byli zatím použíáni k polním pracím a tím nadobro „zkaženi“.

Kohlhase je tak v tomto stavu již nechtěl přijmout, ale požadoval, aby mu byla zaplacena jejich původní hodnota. To mu bylo odepřeno, a když se následně naplnění svého požadavku nedomohl ani u saského kurfiřta, začal se svými pomocníky plenit saské vesnice, přičemž se mu dlouhodobě dařilo unikat po něm pátrající státní moci. Kohlhase se přitom obrací o pomoc ve snaze domoci se jím tvrzeného práva i na Martina Luthera, jenž mu odpovídá svým psaním datovaným 8. prosincem roku 1534.

5 Připomeňme v této souvislosti, že Kleistovým dílem se významně inspiroval i americký spisovatel E. L. Doctorow ve své novele Ragtime, kde je jedním z hrdinů v opětovné pozici „tragického rebela“ snažícího se o dosažení spravedlnosti černošský pianista Coalhouse Walker, jehož křestní jméno tak nepokrytě odkazuje právě k Michaelu Kohlhaasovi. 
Na radu svého druha Nagelschmidta pak ukradne i jisté stříbrné náčiní svému vlastnímu braniborskému kurfiřtu v domnění, že jej tak přinutí, aby se ujal jeho právní záležitosti v Sasku. Nicméně tento jeho záměr nevychází, on sám je braniborskými orgány dopaden, postaven v Berlíně před soud, a společně s Nagelschmidtem odsouzen k trestu smrti lámáním v kole. Ten je pak v Berlíně roku 1540 vykonán. ${ }^{6}$

Toto je tedy stručný nástin skutečného př́běhu, který Kleistovi posloužil jako odrazový můstek pro zpracování jeho novely. Jak ještě uvidíme, Kleist popsanou událost nejen značně přetvořil a upravil pro svoje záměry, ale především zásadně obohatil silou svého tvůrčího ducha právě tak, aby se tento prostý př́běh nakonec stal nadčasovou metaforou neochvějného usilování o dosažení „,vlastních práv“.

Přitom i v jeho pojetí mnohé z právě zmíněného zůstává. Tedy zejména prvotní „,protiprávní napadení“ jeho hrdiny v souvislosti se zabavením a zásadním poškozením jeho koní, stejně jako to, že se v Sasku nemůže domoci nápravy utrpěné škody a reaguje tak na tuto skutečnost násilím, přičemž pro svou přirozenou přitažlivost je využita (a dále rozvinuta) i pasáž, týkající se účasti Martina Luthera na celé záležitosti. Konečně je s původní událostí shodné i vyústění příběhu končícího vynesením trestu smrti nad hlavním hrdinou a jeho vykonáním v Berlíně.

Co je však (pomineme-li další připojená fakta případu, o nichž se samozřejmě ještě zmíníme) nové, je především celkové posunutí příběhu právě do roviny zásadního a vyhroceného střetu práva a bezpráví, jakož i zločinu a trestu, kdy právě Michaelem Kohlhaasem (a nikoliv již skutečným Hansem Kohlhasem) spáchaný zločin vede nakonec k nastolení spravedlnosti, přičemž ta je navíc utvrzena i tím, že Kohlhaas za své vlastní protiprávní jednání bez odporu (ba dokonce ve vnitřním souznění) přijímá i svůj „,nejvyšší trest““. Možná by tak až šlo říci, že skutečnou hlavní postavou příběhu, jíž se nakonec dostane kýženého zadostiučinění, je právě ,„porušené právo“, jež je nakonec ve všech ohledech žádoucím způsobem uspokojeno. Potrestán je nejen původní zločin, který byl podnětem svémoci plodící další trestní jednání, ale právě i tyto další - a ještě závažnější - prohřešky proti existujícímu právnímu řádu.

Zcela konkrétně je tedy v Kleistem líčeném prríběhu Michael Kohlhaas manželem ženy Lisbeth (která také sehraje v celém dění důležitou, ba možná i svým způsobem zásadní roli) a otcem pěti dětí, s nimiž žije jako obchodník s koňmi v Braniborsku. Právě při jedné ze svých obvyklých obchodních cest do Saska však nečekaně narazí u hradu Tronkenburg na mýtnou závoru, jež zde nebývala, a je informován, že se jedná o zeměpanské privilegium ,udělené urozenému pánu Wenzelovi z Tronky“. Kohlhaas tedy zaplatí, následně je však ještě zadržen místním kastelánem, který po něm požaduje ,pas““.7

Ten Kohlhaas nemá a po dalším bezvýsledném jednání mu nakonec nezbývá nic jiného, než nechat zde zástavou své vraníky (pod dozorem jednoho ze svých čeledínů) do té doby, než si pas obstará v Drážd'anech (zde se pak ukázalo, že požadavek na předložení pasu neměl oporu v žádném nařízení a Kohlhaasovi je vydáno i potvrzení v tomto smyslu). Po uskutečnění svých obchodů v Sasku se tedy Kohlhaas vrací pro své vraníky na Tronkenburg, kde se ovšem dočká pro něj šokujících zjištění. V mezidobí došlo totiž k tomu, že jeho již zmiňovaný čeledín byl pro údajně „,nepřístojné chování zbit a vyhnán“, a ve stáji

SCHMIDHÄUSER, E. Verbrechen und Strafe. Mnichov: C. H. Beck, 1995, s. 20-21.

KLEIST, H. Markýza z O ... Praha: Odeon, 1985, s. 7-9. 
pak „místo svých dvou hladkých a dobře živených vraníků spatřil pár vychrtlých, udřených herek“, nebot' koně byli pro nedostatek tažného dobytka zatím bezohledně používáni při polních pracích.

Ani za této situace ale ještě nenechává Kohlhaas průchod svému hněvu, protože - jak to působivě líčí Kleist - ,jeho cit pro právo, který se podobal zlatnickým vážkám, ještě váhal: nebyl ještě před soudnou stolicí svého vlastního nitra jist, je-li jeho protivník obtížen vinou“. Zejména si konkrétně chce ujasnit, zda se snad jeho čeledín opravdu nějak neprovinil. Pokud však nikoliv, pak je ,povinován zjednat sobě zadostiučinění za utrpěné př́koří a svým spoluobčanům do budoucna bezpečnost, je-li celá tato událost podle vší pravděpodobnosti toliko nastrojená“" 8

Když následně zjistí, že čeledín Herse se nijak neprovinil a navíc byl za svou snahu ochránit vraníky na Tronkenburgu krutě a bezprávně ztlučen, rozhoduje se Kohlhaas domoci se svého práva a vydává se do Drážd’an, aby tam podal u soudu žalobu. V ní tedy „za pomoci muže znalého práva“ vylíčil protiprávní jednání urozeného pána z Tronky a „navrhoval jeho zákonné potrestání, navrácení koní do dřívějšího stavu a náhradu škody, kterou tím utrpěl jak on, tak jeho čeledín“.

Věc se přitom zdála být z právního hlediska jasná, nebot' „okolnost, že koně byli nezákonným způsobem zadrženi, vrhala rozhodující světlo na všechno ostatní“. Přesto uplynuly dlouhé měsíce, aniž by Kohlhaas „dostal třeba jen pouhé vyjádření o žalobě, kterou tam u soudu vlastnoručně podal, natožpak samotný rozsudek“. Později se pak prímo od svého „právního přítele“ dozvídá, že „drážd’anský soudní dvůr žalobu na vyšší pokyn vůbec neprojednával".9

Za této krajně neuspokojivé situace ovšem svitla Kohlhaasovi přece jen naděje spočívající ve skutečnosti, že se v Brandenburgu setkává s místním městským hejtmanem, který mu nabízí, že mu „dopomůže k zadostiučinění“ prostřednictvím jeho vlastního zeměpána, tedy kurfiřta braniborského. V tomto smyslu jej tedy i vybízí, ,aby jen napsal krátkou supliku kurfiřtu braniborskému, stručně vyličil, co se událo, přiložil advokátův dopis a dovolával se zeměpánovy ochrany proti násilí, jež na něm bylo na saském území spácháno. Slíbil, že žádost pošle s ostatními písemnostmi kurfiřtovi, který zakročí v jeho prospěch u kurfiřta saského, a víc než takovéhoto zákroku není zapotřebí k tomu, aby mu u drážd’anského tribunálu bylo navzdory kejklům urozeného pána a jeho př́buzenstva dopomoženo ke spravedlnosti“.

Ale i tato naděje na dosažení spravedlnosti je nakonec zklamána, co hưr̆e Kohlhaasovi se dostává sdělení, že je podle „drážd'anského soudu zbytečný kverulant“, nebot' urozený pán mu koně „naprosto nezadržuje“ a má tedy přestat obtěžovat státní kancelár. Pod dojmem této další utrpěné křivdy tak začíná v Kohlhaasovi narůstat touha po dosažení spravedlnosti i „mimoprávní cestou“, od čehož ho ale zatím zrazuje jeho žena Lisbeth, která se dokonce sama nabídne, že pronikne v Berlíně př́imo k panovníkovi (nebot’ ženě může být něco takového mnohokrát snadnější než muži) a předá mu jeho žádost.

Takto však začíná v př́iběhu i skutečná tragédie, nebot' Lisbeth je při pokusu o předání žádosti těžce zraněna, a po návratu domů na následky tohoto zranění umírá. Právě při jejím pohřbu je mu pak doručeno i panovníkovo rozhodnutí ohledně žádosti, která se nakonec

Tamtéž, s. 11-12.

Tamtéž, s. 16-17. 
přeci jen dostala do jeho rukou, a sice ,,aby koně odvedl z Tronkenburgu a pod trestem uvržení do žaláře dál si v této věci nestěžoval“. ${ }^{10}$

Není tak ani nikterak nepochopitelné, že pokud dř́ve Kohlhaas snad ještě váhal nad tím, zda se v zájmu dosažení spravedlnosti má vydat cestou svémoci, tak nyní - po faktickém vyčerpání všech dostupných právních prostředků a pod zorným úhlem neštěstí, které jej postihlo, již tyto pochybnosti nemá. Přesto se ještě naposled pokouší i o dosažení svého cíle nenásilnou cestou, jakkoliv tato již nemá oporu v platném právu.

Kohlhaas totiž ,usedl a sepsal rozsudek, v němž z moci sobě vrozené odsuzoval šlechtice Wenzela z Tronky k tomu, aby ve třech dnech po přečtení přivedl do Kohlhaasenbrücku vraníky, které mu odňal a na svých polích ztrhal, a osobně je v jeho stáji vykrmil““. Jelikož pak po odeslání tohoto „rozsudku“ neobdržel ve stanovené lhůtě odpověd', prodal Kohlhaas dům a poslal své děti za hranice, aby tak byl zcela volný pro záměr, od kterého již nebylo možno ho odvrátit.

Následně pak se svými věrnými pacholky (mezi nimiž nechyběl ani již zmiňovaný a dř́ve krutě zbitý Herse) vytáhl na Tronkenburg, kde pak již konal jako př́islovečný „,anděl pomsty“, jehož řádění neunikli ani kastelán a správce, kteří se na spáchaném bezpráví sami významně podíleli (,,vyletěly za Herseho jásotu z otevřených oken kastelánova obydlí mrtvoly kastelána i správce, jakož i ženy a dětíc). Také hrad je vypálen a vyrabován, samotnému hradnímu pánu Wenzelovi z Tronky - na nějž měl Kohlhaas nejvíce spadeno - se však podařilo v poslední chvíli uniknout.

Po této akci již není cesty zpět a hlavní hrdina př́iběhu tak dokonce vyhlašuje „Kohlhaasův mandát“", „, němž vyzýval zemi, aby urozenému pánu Wenzelovi z Tronky, s nímž vede spravedlivou válku, neposkytovala nižádnou pomoc, naopak zavazoval každého obyvatele, jeho př́ibuzné a přátelé nevyjímajíc, aby mu ho vydal, pod pohrůžkou, že přijde o hrdlo a že mu neúprosně položí popelem vše, cokoli by snad zval svým majetkem“. ${ }^{11}$

Pronásledování Wenzela z Tronky je však neúspěšné, takže Kohlhaas v čele stále narůstajícího houfu svých podporovatelů (mezi nimiž jsou ovšem vcelku pochopitelně mnohdy lidé „pochybné pověsti“) nakonec oblehne Wittenberg, kde se má „urozený pán“ skrývat $\mathrm{a}$ - když jej místní obyvatelé v rozporu s jeho př́kazem nevydají - město nakonec na několika stranách podpálí. To se pak opakuje (také proto, že vojenské pokusy o potření rabujících oddílů jsou zbrklé a neúspěšné), takže se Kohlhaas postupně stává „kletbou města Wittenbergu a zkázou Saska“, nebot’ řádění jeho družiny se přenáší i na další saské území, kdy podpáleno je dokonce také Lipsko.

Kohlhaas při té př́ležitosti sestavil další „mandát“, v němž „,se nazýval místodržitelem archanděla Michaela, který přišel ztrestat ohněm a mečem záludnost, jíž propadl celý svět, na všech, kteří se v tomto sporu přikloní na stranu urozeného pána“. Tato „spasitelská dikce“ tak přivádí v Kleistově pojetí na scénu i Martina Luthera, který v reakci na toto prohlášení formuluje list, ,jenž byl přibit ve všech městech a osadách kurfiřtství““.

V něm pak mimo jiné ř́ká - „Kohlhaasi, který předstíráš, že jsi byl poslán, abys třímal meč Spravedlnosti, co se to, smělče, v šílenství zaslepené vášně opovažuješ, ty, jenž jsi sám od hlavy až k patě naplněn nespravedlností? Protože ti zeměpán, jemuž jsi poddán, odepřel právo v rozepři o nicotný majetek, povstáváš, bezbožníku, s ohněm a mečem

10 Tamtéž, s. 24.

11 Tamtéž, s. 27. 
a vpadáš jako vlk pouště do pokojné obce, kterou on ochraňuje? ... Jak můžeš ty, jehož lítá hrud', poštívána choutkou svémocné pomsty, upustila po prvních lehkovážných pokusech, které ztroskotaly, od úsilí zjednat si právo, prohlašovat, že ti bylo právo odepřeno? ... Věz, že meč, jímž máváš, je meč loupení a vraždy, rebel jsi a ne bojovník spravedlivého Boha, a tvojí odplatou na tomto světě je kolo a šibenice a na onom věčné zatracení, kterýmžto jsou trestány zločin a bohaprázdnost."12

Z této obsáhlé citace je tak snad patrné, že Kleist jednak upomíná na známé Lutherovy postoje z doby ,selských válek“, kdy se tento jednoznačně postavil na stranu vrchnosti proti vzbouřeným sedlákům, jednak ale i záměrně ,jiným pohledem“ skálopevného obhájce řádu zpochybňuje Kohlhaasovo jednání, jež se zatím v jím líčeném příběhu zdálo být když už ne př́mo oprávněné, tak jistě alespoň velmi dobře pochopitelné.

Sám Kohlhaas je přitom listem velmi zasažen, doslovně - ,ale kdo popíše, co se dálo v jeho duši, když ... spatřil list, jehož obsah jej obviňoval z nespravedlnosti, podepsaný nejdražším a nejúctyhodnějším jménem, které znal, jménem Martina Luthera!“ Vnitřní potřeba ospravedlnit se a získat souhlas se svým konáním, jehož cílem přeci není nic jiného než náprava spáchané nespravedlnosti, jej tak v přestrojení vede až do Lutherovy světnice ve Wittenbergu, kde se odehraje další zásadní zlom v tomto podivuhodném př́iběhu o právu a bezpráví.

Po delší rozmluvě totiž Kohlhaas skutečně přesvědčí Luthera, jenž je ohromen jeho neochvějným lpěním na tom, aby se mu dostalo spravedlnosti, o čistotě svých pohnutek, takže tento následujícího dne napíše dopis saskému kurfiřtovi, ve kterém jej vyzve, aby udělil koňařovi amnestii a mohlo tak následně dojít k obnovení jeho procesu. To se pak - avšak po delším zvažování, kdy jsou kurfiřtovými úředníky a rádci předestřena různá právní stanoviska - skutečně stane, a Kohlhaas je veřejným listem informován, že obdrží pokud ,do tř́ dnů po přečtení tohoto listu složí zbraně, jichž se chopil, svobodný glejt do Drážd'an za účelem nového prošetření jeho záležitosti““. ${ }^{13}$

Kohlhaas hned na to tedy rozpouští svůj ozbrojený houf, aby se následně „dostavil podle privilegia uděleného mu panovníkem do Drážd'an, aby u soudu podal na urozeného pána Wenzela z Tronky žalobu kvůli svým vraníkům“. Sám Kohlhaas je zde hlídán ozbrojenou stráží určenou nejprve pro jeho ochranu, jež se však postupně proměňuje v ty, kdo fakticky dozírají nad jeho vězněním. To je pak dáno proměnou náhledu na jeho při, kdy „, soukromých domech i na veřejných místech se ozýval názor, že je lépe dopustit se na něm veřejné křivdy a celou věc znovu zamítnout, než mu v takové nicotné věci učinit po právu, vyvzdorovaném násilnými činy, jen proto, aby byla uspokojena jeho šílená umíněnost“". Zejména mu uškodí, že jeho dřívější kumpán z ozbrojeného houfu Johann Nagelschmidt se rozhodl ,pokračovat na vlastní pěst v řemesle, na jehož stopu ho přivedl Kohlhaas“, přičemž se ovšem dále nazývá „Kohlhaasovým náměstkem“, čímž zákonitě budí i dojem, že je s koňařem ve spojení, a ten je tedy s jeho násilnými činy srozuměn. ${ }^{14}$

Kohlhaas se sice snaží toto podezření rozptýlit, když však pochopí, že situace je víceméně beznadějná a on se v rozporu s glejtem stal v Drážd’anech skutečným vězněm, sám Nagelschmidta osloví s prosbou o pomoc s útěkem, aby potom opět velel ozbrojenému

\footnotetext{
Tamtéž, s. 33-34.

Tamtéž, s. 42.

Tamtéž, s. 51-53.
} 
houfu. Netuší však, že je obětí léčky, a posel listu jej bez odkladu předá úřední instanci, což má za následek, že Kohlhaas je „odsouzen, aby byl katovými holomky štípán rozžhavenými kleštěmi, rozčtvrcen a jeho tělo spáleno mezi kolem a šibenicíi. ${ }^{15}$

$\mathrm{V}$ této pro něj již zcela beznadějné situaci však ,povstal kurfiřt braniborský, aby jej zachránil z rukou moci a zvůle, a domáhal se nótou, zaslanou kurfiřtské státní kanceláŕi, jeho vydání jakožto braniborského poddaného“. Dochází tak k rozepř́ím o jurisdikci v př́ípadu, kdy se v Sasku nejprve diví „nevlídnosti a nespravedlnosti, s nimiž je drážd’anskému dvoru upíráno právo soudit Kohlhaase podle zákona pro zločiny, jichž se dopustil v této zemi“, následně se však i z politických důvodů uvolují žádosti braniborského kurfiřta vyhovět, přičemž ovšem ale hodlají do věci zapojit i ř́šskou soudní instanci, nebot' saský kurfiřt se rozhodl, že ,„předloží Jeho císařskému Veličenstvu ve Vídni zprávu o jeho ozbrojeném vpádu do Saska, že si bude stěžovat na porušení provolaného jím veřejného zemského míru a žádat Jeho císařské Veličenstvo, nebot' není vázáno žádnou amnestií, aby říšským žalobcem pohnalo pro to Kohlhaase u dvorního soudu v Berlíně k odpovědnosti““. ${ }^{16}$

O týden později je tak Kohlhaas skutečně v okovech poslán do Berlína, přičemž průběh cesty je obohacen i o romantickou příhodu s cikánkou znající další osud saského kurfiřta a jeho rodu, jehož popis na lístku vloženém do amuletu svěří Kohlhaasovi s tím, že si jím v budoucnu může vykoupit život (tuto poměrně obsáhlou ,větev příběhu“ zde ale již nebudeme dále sledovat, nebot' nikterak blíže nesouvisí s fenoménem „práva a literatury“ v Kleistově novele, jenž je hlavním předmětem zájmu tohoto pojednání).

Kohlhaas sám byl tedy v Berlíně povolán ,„po př́ijezdu vídeňského císařského prokurátora před soud, aby se odpovídal z porušení obecného císařského zemského míru, a třebaže již ve svých výpovědích namítal, že pro ozbrojený vpád do Saska a násilnosti při něm páchané nelze na něho nastupovat pořadem práva, nebot's kurfiřtem saským uzavřel na Lužíně smír, zvěděl přece jen k svému poučení, že Jeho císařské Veličenstvo, jehož prokurátor tu vznáší stížnost, nemůže na to brát zřetel“. S tím se však brzy smíŕí, když mu vysvětlili, že naopak ve sporu s urozeným pánem Wenzelem z Tronky se mu dostane plného zadostiučinění.

Kohlhaas je za porušení zemského míru odsouzen k trestu smrti stětím, nicméně v den výkonu popravy se dozvídá i o výsledku v Drážd'anech paralelně vedeného soudního sporu proti Wenzelovi z Tronky, v němž byla bod po bodu skutečně konečně uznána jeho žaloba, takže braniborský kurfiřt př́ímo na popravišti může prohlásit: „Nu, Kohlhaasi, dnes je den, kdy se ti dostává práva! Pohled', zde ti vracím všechno, oč jsi na Tronkenburgu násilím přišel: vraníky, šátek na krk, říšské zlato, prádlo, ba dokonce i léčebné za tvého čeledína Herseho padlého u Mühlbergu. Jsi se mnou spokojen?“17

Kohlhaas sám pak ,pročítal užaslýma, rozzářenýma očima nález, který mu byl na arcikancléřùv pokyn odevzdán, a když v něm našel odstavec, jímž byl urozený pán Wenzel odsuzován k dvěma rokům vězení, klesl, přemožen city ... zpovzdálí před kurfiřtem na kolena“. Kohlhaasovi je pak ještě dopřáno, aby se potěšil se svými opětovně vykrmenými

Tamtéž, s. 60.

Tamtéž, s. 62.

Tamtéž, s 79-80. Pokud se samotného deliktu „porušení zemského míru“ („Landfriedensbruch“) dotýká, je možno připomenout, že má své kořeny v tzv. „Božím míru“ (,treuga Dei“), a že zákonodárství k němu vztažené se objevuje na říšském území již počátkem 12. století (poprvé roku 1103). Samotný způsob trestání tohoto deliktu přitom dlouho zůstával nejednotný. 
a dobře udržovanými koňmi, nicméně potom je kurfiřtem vyzván, aby sám složil účty spravedlnosti - „A nyní se, koňaři Kohlhaasi, když se ti takto dostalo zadostiučinění, připrav, abys i ty dal Jeho císařskému Veličenstvu, jehož plnomocník zde stojí, zadostiučinění za porušení jeho zemského míru!“ Kohlhaas tedy po rozloučení se svými dětmi „zamířil na popraviště, kde jeho hlava padla pod katovou sekyrou“. ${ }^{18}$

I z tohoto základního nástinu př́iběhu je tak velmi dobře patrné, že Kohlhaasův prríběh je v Kleistově podání opravdu fascinujícím vylíčením cesty prostého muže za spravedlností, jíž je připraven obětovat doslova vše, včetně štěstí vlastní rodiny a vlastního života. Přijmout život v potupě, ve výsměchu spravedlnosti a při spolknutí urážek v kapitulaci před mocnými, kteří jsou schopni pro své vlastní zájmy ohnout i justici - jak to většina v takové bezvýchodné situaci učiní (a žel i dnes a v „právním státě“ se nepochybně takové př́ípady někdy odehrávají), prostě není nic, co by byl schopen a ochoten akceptovat.

Proto jsou tím ostatně všichni (včetně čtenářů tohoto nadčasového díla) tolik překvapeni a zaraženi, namísto smírené rezignace jsou konfrontováni s odhodláním domoci se spravedlnosti doslova za každou cenu, ba i za cenu páchání vlastních činů nespravedlnosti a za cenu vlastního života. Tím pak zároveň vznáší toto dílo logicky také varování před tím, abychom záležitosti spravedlnosti brali kdykoliv - a to i v zdánlivě nedůležitých věcech - na lehkou váhu, protože nikdy nevíme, jak vážná je věc pro důstojnost toho, jemuž spravedlnost odepřeme.

Konečně při zařazení tohoto prríběhu do celku „právo a literatura“ ani nezapomínejme, že vedle hlavního problému, jímž je právě „odepření spravedlnosti“, je zde i celá řada dalších zajímavých ,právních momentư“, kvůli nimž si příběh zaslouží naši pozornost. Tak bychom zejména mohli vyzvednout skutečnost, že se př́běh vztahuje k rozdílným jurisdikcím - saské a braniborské -, přičemž samotný trest smrti si nakonec Kohlhaas odpyká za porušení říšského práva zemského míru. K tomu se pak váže i otázka amnestie udělené v Sasku, jakož i některé další dílčí aspekty.

Jakkoliv je ovšem tato problematika pro směr „právo a literatura“ důležitá a zajímavá, není však - jak již zmíněno v úvodu tohoto textu - v kontextu celého Kleistova díla zdaleka ojedinělá. V následujícím textu se tedy - jakkoliv již v mnohem stručnějším a spíše jen informativním záběru - budeme věnovat i dalším položkám autorovy tvorby, jež je záhodno v této souvislosti zmínit.

\section{Další Kleistova díla vztahující se k problematice směru ,právo a literatura“6}

Konkrétně bude naše pozornost patřit dvěma povídkám a dvěma divadelním hrám. První z povídek, „Souboj“, se přitom odehrává někdy koncem 14. století, a jak již samotný název trochu napovídá, jejím jádrem je „Boží soud“ konaný ve formě soudního souboje. Rezignujeme zde přitom na podrobné vylíčení dosti komplikované zápletky a konstatujeme pouze, že se jednalo o spor o čest vdovy paní Littegardy z Auersteinu, dcery zemského správce Winfrieda Bredy, jež údajně strávila noc s Jakubem Rudovousem, jak alespoň tento tvrdí.

Dotyčná je následně po tomto tvrzení vyhnána svou rodinou, přičemž útočiště nakonec nachází u svého blízkého přítele a komořího pana Friedricha z Troty, který věří jejímu tvrzení, že se jedná o nepravdivé osočení. A nezůstává jen u slov, nebot' když se koná soud v Basileji, prohlásí, ,že on sám je rozhodnut nevinu paní Littegardy na bezbožném činu,

18 Tamtéž, s. 80. 
z něhož ji hrabě nařkl, dokázat před celým světem v zápase na život a na smrt podle Božího soudu!“ Věc přitom byla nanejvýše vážná, protože v případě prohry Friedricha z Troty čekala na jak na něj, tak i na paní Littegardu hranice. A jelikož vnější okolnosti svědčí spíše pro její provinění (hrabě Jakub Rudovous se mohl vykázat i jejím prstenem, který mu údajně věnovala), je proto zapřísahána matkou a sestrou pana Friedricha, aby se v př́padě své viny raději přiznala. Ona však tvrdí, že její svědomí nezatěžuje žádná vina, a tak nadchází den svaté Markéty, během něhož se má v Basileji odehrát tento „soudní souboj“. ${ }^{19}$

Při něm je pak Jakub Rudovous jen lehce poraněn, zatímco obhájce Littegardiny cti pan Friedrich z Troty dle všeho zraněn smrtelně. Nakonec se však překvapivě brzy ze svých zdánlivě fatálních zranění uzdravuje, odmítá uznat svou porážku, nicméně musí nakonec uznat tvrzení své matky, která říká, ,že platí zákon, podle něhož zápas, který je jednou podle výroků soudců ukončen, již nikdy nesmí být obnoven k vybojování téže věci na kolbišti Božího soudu“. Naopak „mezitím u tribunálu zřízeného císařem v Basileji byla proti panu Friedrichovi z Troty jakož i jeho přítelkyni, paní Littegardě z Auersteinu, vznesena žaloba pro hříšné vyzvání Božího soudu a oba byli dle platného zákona odsouzeni k potupné smrti v plamenech př́imo na kolbišti“ 20

Této popravě má být na císařovo prání přítomen i hrabě Jakub Rudovous, přičemž se ovšem zjišt’uje, že jeho v soudním souboji utrpěné a zdánlivě jen velmi lehké zranění nakonec zapříčinilo hnisavý kostižer, který se nezastavil ani poté, co mu byla odejmuta poraněná ruka, a hrabě tak umírá. Přitom vychází i najevo, že ve skutečnosti (aniž o tom ovšem tehdy věděl) strávil dotčenou noc s Littegardinou komornou, která mu věnovala prsten předtím odcizený své paní.

V důsledku tohoto skutečného ,zásahu Prozřetelnosti“ jsou Littegarda a její ochránce doslova v posledním okamžiku zachráněni, a císař ,,dal do statutů svatého božího souboje všude, kde se předpokládá, že jím vina bezprostředně vyjde najevo, vepsat slova, je-li to vůle boží “. ${ }^{21}$ Každopádně můžeme říci, že Kleist takto svým vyprávěním vytvořil velmi zajímavý př́iběh „Božího soudu“ konaného ve formě „soudního souboje“ (judicium pugnae), kdy Bůh se přesně v souladu se záměry tohoto ordálového důkazního prostředku projevil jako pozorný strážce hledané pravdy, byt' ji nechal vyjevit nanejvýš podivuhodným způsobem (nebot' zdánlivý výsledek souboje postupným vývojem situace zcela „,převrátil““) a s výrazným smyslem pro dramatické rozuzlení doslova „,na poslední chvíli““.

Konečně lze do celku „právo a literatura“ zařadit i další Kleistovu povídku „Markýza z O ...", která tu právě zmíněnou o soudním souboji ostatně připomíná i svým neobvyklým dějem a rozuzlením. Zasazena je však do doby přeci jen novější, byt' úplně konkrétní autor v tomto př́padě není. Má se však za to, že svou inspiraci čerpal z jednoho poněkud anekdotického př́běhu obsaženého v jednom z esejí Michela de Montaigne. ${ }^{22}$

19 Tamtéž, s. 189-201. Koncept „Božího soudu“ (ordalium, judicium Dei) vycházel z dobového přesvědčení, že Bůh je ochranitel práva, který nestrpí, aby v pozemském právním sporu byl viník osvobozen, a naopak nevinný odsouzen. Pokud by hrozilo toto nebezpečí, dá tedy o vině obžalovaného sám Bůh rozhodné „,nebeské znamení“. Forem takovéhoto Božího soudu bylo vícero (např. ordál ohněm či vodou), a jednou z nich byl právě i soudní souboj.

20 Tamtéž, s. 208.

21 Tamtéž, s. 214.

22 SCHMIDHÄUSER, op. cit., s. 235-236. 
Tento ovšem svébytně rozvíjí, přičemž jádrem zápletky je skutečnost, že markýza z názvu povídky žádá v novinovém inzerátu, aby se jí ohlásil otec dítěte, jež má porodit, jelikož jednoduše vůbec netuší, kdo jím je. Jak následně vyjde najevo, je otcem ruský hrabě, důstojník, který ji nejprve zachránil během válečného konfliktu před znásilněním ze strany svých vojáků (ti byli kvůli tomuto pokusu následně popraveni), následně se jí ale sám zmocnil poté, co upadla do mdlob, takže byla po zjištění svého těhotenství touto skutečností naprosto překvapena a šokována, a přes ujišt’ování o své nevině také zapuzena svými rodiči. Hrabě sám, který podle všeho podlehl okamžitému impulsu, se přitom snaží pojmout ji za manželku, aniž jí ovšem vysvětlí, co je příčinou jeho překotné snahy. Nakonec se jí přizná, avšak až delší dobu po velmi formálním sňatku a narození syna se mu také podaří získat její skutečnou prrízeň a lásku. ${ }^{23}$

Otázka zločinu a trestu je tak zřejmá, hrabě sám se dopustil toho, v čem původně zabránil svým vojákům, a za co tito byli následně popraveni. Je tedy jen logické, že i on by měl být při nestranném chodu spravedlnosti potrestán stejně. Lze tak vést úvahy, nakolik je za zcela jiným vyzněním stejného činu skryto stavovské hledisko, či nakolik lze jednání hraběte omluvit polehčujícími okolnostmi, jež jsou v př́iběhu naznačeny.

Každopádně lze i tento př́běh jistě zařadit do směru ,právo a literatura“, přičemž ještě výrazněji lze takovéto nastavení zdůraznit u obou již také zmiňovaných Kleistových divadelních her. První z nich, „Rozbitý džbán“, nás přitom přesvědčuje, že kromě brilantního zvládnutí vážných témat disponoval Kleist i nemalým smyslem pro humor a nečinilo mu sebemenší problém napsat i rozvernou frašku, protože právě o tu se v tomto případě zejména jedná.

V ději totiž nejde o nic menšího než o vyšetřování př́ípadu rozbitého džbánu, kterého se ujímá rychtář Adam, jenž je ovšem, jak se ve skvěle rozvíjené zápletce postupně ozřejmí, sám pachatelem tohoto činu. Celé jeho snažení nalézt viníka, kterého pochopitelně více než dobře zná, a logicky se jej snaží utajit tím, že najde „nějakého nepravého“, je ovšem zásadně komplikováno, protože na inspekci k němu téhož dne dorazil i soudní rada Pánek. Ten se vývoji soudního líčení nestačí divit, než se konečně dovtípí, co je z předvedeného soudního dokazování už víceméně zřejmé. Fraška takto přechází i do ostré satiry na celý tehdejší soudní systém, jehož ostrou kritikou si Kleist rozhodně nebral servítky. Přesto však tento prŕběh „,výmluvné lži a utajené pravdy“ raději místně přesadil z rodného Pruska do patriarchálně vylíčeného Nizozemí. ${ }^{24}$

Druhá z Kleistových her „Princ Bedřich Homburský“ týkající se „práva v literatuře“ v sobě opět má částečně i některé humorné aspekty, celkově se však vztahuje k vážnému tématu neuposlechnutí vydaného rozkazu v armádě, z kterého - přestože právě porušení tohoto konkrétního rozkazu znamená nakonec v dané bitvě vítězství - může vzejít pro hlavního hrdinu poprava na základě odpovídajícího rozsudku válečného soudu. Jím je totiž princ Bedřich Homburský skutečně odsouzen k trestu smrti zastřelením, těsně před výkonem rozsudku je však přeci jen omilostněn rozhodnutím kurfiřtovým, který nemůže takto nechat odejít ze světa hrdinu svých vojáků a svého lidu, jak je za všeobecného souhlasu a provolávání slávy princovi ze strany př́tomných důstojníků také uznáno. ${ }^{25}$

\footnotetext{
23 KLEIST, Markýza z O ..., s. 83-115.

24 KLEIST, Záhadný nesmrtelný, s. 28-103.

25 Tamtéž, s. 306-400.
} 
Souhrnně tak po podrobnějším i velmi stručném hodnocení Kleistova díla vyznačujícího se vazbou na „právo a literaturu“ můžeme konstatovat, že skutečně snad právě a zejména tyto jeho práce naplňují primárně „osvícenský předpoklad, že nad celým lidstvem vládne jeden velký, neúprosný zákon, jemuž je podřízen člověk největší stejně jako žebrák. Ctnost je odměňována, nepravost trestána - předpoklad, kterému Kleist spíše chtěl věřit, než skutečně věřil, jinak by si jej nepotřeboval s takovou úporností znovu a znovu, v životě i díle, ověřovat a zdůvodňovat" ${ }^{26}$

26 STROMŠÍK, op. cit., s. 32. 